\title{
Short-term effects of passive restoration in springs habitats in Southern Brazil
}

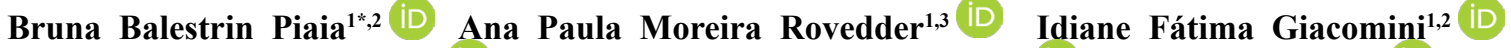 \\ Roselene Marostega Felker ${ }^{4}$ iD Maureen de Moraes Stefanello ${ }^{1,5}$ (iD) Betina Camargo ${ }^{1,5}$ (iD) \\ Djoney Procknow ${ }^{1,5}$ iD Jéssica Puhl Croda ${ }^{1,2}$ iD
}

${ }^{1}$ Núcleo de Estudos e Pesquisas em Recuperação de Áreas Degradadas (NEPRADE), Universidade Federal de Santa Maria (UFSM), Santa Maria, RS, Brasil. *Corresponding author. E-mail: brunabpiaia@gmail.com.

${ }^{2}$ Programa de Pós-graduação em Engenharia Florestal, Universidade Federal de Santa Maria (UFSM), Santa Maria, RS, Brasil. ${ }^{3}$ Departamento de Ciências Florestais, Universidade Federal de Santa Maria (UFSM), Santa Maria, RS, Brasil.

${ }^{4}$ Instituto de Meio Ambiente de Santa Catarina (IMA), Florianópolis, SC, Brasil.

${ }^{5}$ Programa de Pós-graduação em Engenharia Agrícola, Universidade Federal de Santa Maria (UFSM), Santa Maria, RS, Brasil.

ABSTRACT: This study analyzed natural regeneration floristic patterns in spring habitats submitted to different ecological restoration actions in the seasonal forest in Atlantic Forest biome, Rio Grande do Sul. We assessed floristic composition in six springs before restoration actions and 12 months later. We identified and counted all regenerating individuals with height greater than or equal to $30 \mathrm{~cm}$ and diameter at breast height less than or equal to $5 \mathrm{~cm}$ in eight plots in each spring. The richness and abundance of each spring and assessment were compared by the Kruskal-Wallis test $(P<0.05)$. Detrended Correspondence Analysis (DCA) was performed to verify floristic patterns and association between species. Results showed an increase in richness and abundance after ecological restoration implementation. The DCA showed a distinct floristic composition between springs. The springs remaining natural vegetation and the successional stage of these vegetation influenced the natural regeneration floristic composition pattern. Passive restoration, which was effective by enclosure, favored natural regeneration recruitment. Key words: permanent preservation area, ecological restoration, floristic composition, passive restoration.

Efeitos de curto prazo da restauração passiva em habitats de nascentes no sul do Brasil

RESUMO: O objetivo deste estudo foi analisar os padrões florísticos da regeneração natural em habitats de nascentes submetidos a diferentes ações de restauração ecológica na floresta estacional do bioma Mata Atlântica, Rio Grande do Sul. A composição florística foi avaliada em seis nascentes antes das ações de restauração e 12 meses depois. Todos os individuos regenerantes com altura maior ou igual a 30 $\mathrm{cm}$ e diâmetro à altura do peito menor ou igual a $5 \mathrm{~cm}$ foram contados e identificados em oito parcelas em cada nascente. A riqueza e abundância de cada nascente em cada avaliação foram comparadas pelo teste de Kruskal-Wallis $(P<0,05)$. A Análise de Correspondência Retificada (DCA) foi realizada para verificar os padrões florísticos e a associação entre as espécies. Os resultados mostraram um aumento na riqueza e abundância após a implementação da restauração ecológica. A DCA apresentou uma composição florística distinta entre as nascentes. A vegetação natural remanescente nas áreas de nascente e o estágio sucessional da vegetação influenciaram o padrão de composição florística. A restauração passiva, efetivada pelo cercamento, favoreceu o desenvolvimento da regeneração natural. Palavras-chave: área de preservação permanente, restauração ecológica, grupos florísticos, restauração passiva.

\section{INTRODUCTION}

A spring is where groundwater discharges to the ground surface creating a visible flow. Springs are among the most valuable and ecologically interesting ecosystems. Protection of springs is not only a question of protecting the physical feature defined as the spring, but it is also essential to preserve its surroundings to provide ecosystem functions and services, manly water quality. These fragile ecosystems are of great importance to regional biodiversity, but they are currently threatened by groundwater abstraction and pollution, habitat degradation, land use and global warming.

The degradation of forest formations in spring habitats leads to a loss of habitats and 
connectivity (BOESING et al., 2018), and a loss of biodiversity and ecosystem services (ROVEDDER et al., 2016). As these ecosystem services, we highlighted the control of surface erosion, river flow regulation, biogeochemical cycling, microclimate and improvement of water quality (MEA, 2005). So, the conservation and ecological restoration of these habitats are very important. In addition, the Brazilian legislation defines a minimum radius of 50 meters to preserve these habits called Permanent Preservation Area (PPA) (BRAZIL, 2012). When the spring was degraded the legislation requires the restoration to return to ecological function and ecosystem service.

In this sense, ecological restoration provides solutions to these environmental problems because it enables structure and functionality reconstruction of biological communities (MARTIN, 2017). Ecological restoration methods and actions must be adopted in order for ecological processes to return. These methods and actions must end the impact sources and provide conditions for establishing propagules so that the natural cover returns and the site has the capacity to restore its functions (NERY et al., 2013).

Among the ecological restoration methods, the passive restoration is one of lower cost approaches which uses the local regeneration potential and presents better results in landscapes with a high level of habitat connectivity (CROUZEILLES et al., 2017). At the other extreme, there are intensive strategies such as planting seedlings in a total area, called active restoration (RODRIGUES et al., 2009; RODRIGUES et al., 2011). Nucleation strategies such as planting in dense nuclei are an intermediate alternative with less intervention (BECHARA et al. 2016).

There is a general lack of scientific information regarding the specificities of the restoration methods mentioned above in southern Brazil, which has a subtropical climate (ROVEDDER et al., 2014), precisely in spring habitats. The suppression history and conversion of natural sites, as well as studies on the potential for natural regeneration (MMA, 2017) in Atlantic forest have showed the urgency of policies and programs based on ecological restoration principles.

In this context, the objective of this study was to analyze natural regeneration floristic composition patterns of springs habitats under ecological restoration by different restoration actions in the Atlantic Forest, Rio Grande do Sul.

\section{MATERIALS AND METHODS}

The study was carried out in six springs in the sub-hydrographic basin of Arroio Manoel Alves in the central region of Rio Grande do Sul (Figure 1). This sub-hydrographic basin is inserted in the Atlantic Forest and is part of the Ecological Corridor of the Fourth Colony, an important remaining of the Seasonal Forest (IBGE, 2012). There is also Mixed Ombrophilous Forest in small proportions (MARCHIORI, 2002). The relief is undulating with Cambisol and Litholic Neossol predominating in association with Regolithic Neossol soils (STRECK et al., 2008). The region's climate is Cfa humid subtropical according to the Köppen climate classification, with hot summers and without a defined dry season. The average temperature of the hottest month is $22{ }^{\circ} \mathrm{C}$, the coldest month is $12.2{ }^{\circ} \mathrm{C}$ and the average altitude is $400 \mathrm{~m}$ (ALVARES et al., 2013).

The sub-hydrographic basin of Arroio Manoel Alves had its riparian forests strongly impacted by anthropic actions regarding its use and soil occupation and the suppression of native vegetation around many springs. The main disturbance sources in the Permanent Preservation Areas (PPAs) of the springs were the suppression of native vegetation cover and replacement by Eucalyptus sp. forestry and cattle raising (Table 1), with Eucalyptus sp. forestry being the main economic activity in the subhydrographic basin. The six springs evaluated were fenced and received different restoration approaches in 2014, with the exception of the N6 spring, which was fenced 8 years earlier (Table 1). All six springs were perennial and punctual. The fenced area of each spring site was 0.78 ha and the characteristic of six springs assessed were:

N1 - applied nucleation: Spring habitat with approximately $10 \mathrm{~m}$ radium of native vegetation in medium successional stage around the spring. Eucalyptus sp. forestry in the rest of the area with cattle free access. This site was isolated with a fence, the Eucalyptus sp. trees were removed and seedlings were planted in nuclei. We implanted 40 nuclei of 5 seedlings each, randomly containing the following species: Eugenia involucrata DC., Schinus terebentifolia Raddi, Allophylus edulis (A.St.-Hil., Cambess. \& A. Juss.) Radlk., Luehea divaricata Mart. \& Zucc., Campomanesia xanthocarpa O.Berg, Cupania vernalis Cambess., Prunus myrtifolia L.(Urb.), Eugenia uniflora L., Parapiptadenia rígida (Benth.) Brenan and Psidium cattleianum Sabine.

N2 - total area seedling planting: Spring habitat with Eucalyptus sp. forestry and pasture 


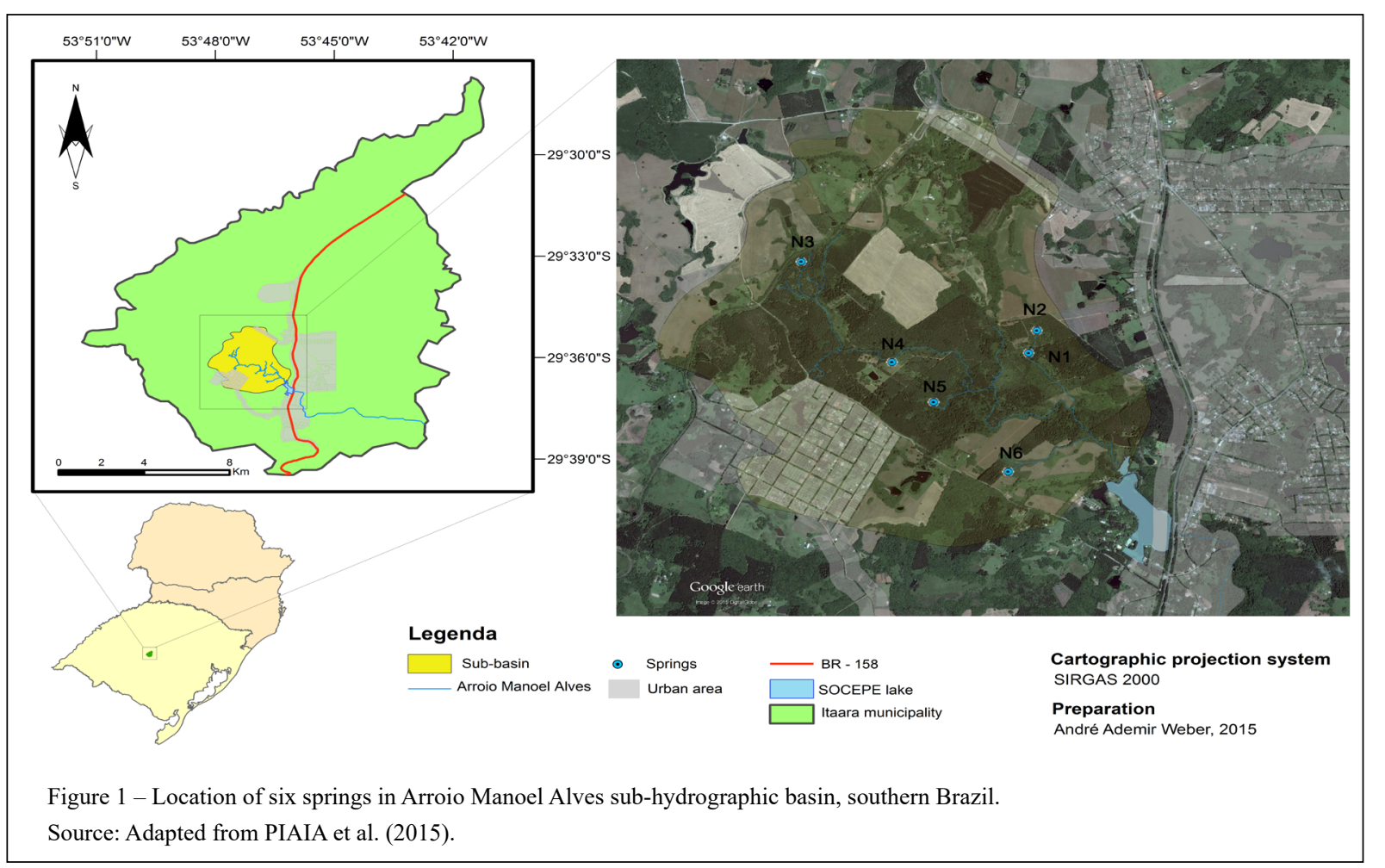

that cattle had free access. This site was isolated with a fence and had seedling planting in total area with $2 \times 3$ distance between seedlings of the following species: Luehea divaricata Mart. \& Zucc., Parapiptadenia rigida (Benth.) Brenan, Psidium cattleianum Sabine, Schinus terebentifolius Raddi, Cupania vernalis Cambess., Eugenia involucrata DC., Allophylus edulis (A.St.-Hil., Cambess. \& A. Juss.) Radlk., Campomanesia xanthocarpa O.Berg, Blepharocalyx salicifolius (Kunth) O. Berg, Prunus myrtifolia L.(Urb.), Eugenia uniflora L. and Vitex megapotamica (Spreng.) Moldenke.

N3 - passive restoration: Degraded spring habitat with Eucalyptus sp. forestry and pasture with cattle free access. This site was isolated with a fence.

N4 - passive restoration: Disturbed spring habitat with native forest in medium successional stage with free cattle access. The site was fenced to remove cattle access.

N5 - passive restoration: Disturbed spring habitat with native forest in medium to advanced successional stage in half part of PPA zone and Eucalyptus sp. forest in the other half part. Cattle had free access so the site was fenced.

N6 - eight years passive restoration: Spring habitat isolated by fence eight years ago in earlier to medium successional stage. The site had Pinus sp. forest and cattle free access before isolation.
The vegetation data was assessed in eight plots of $2 \mathrm{~m} \times 2 \mathrm{~m}$ in each spring systematically installed in the Permanent Preservation Area (PPA) and forming a cross-section (FLOSS et al. 2018). Four plots were installed at five meters from the spring in each of the four cardinal directions (north, south, east, west) and another four plots at 30 meters from the spring, arranged at an angle of $45^{\circ}$ in relation to other plots. All regenerating shrub and arboreal individuals with a height greater than or equal to $30 \mathrm{~cm}$ and a diameter at breast height (DBH) less than or equal to $5 \mathrm{~cm}$ were counted and identified.

We carried out the first assessment before implementing the restoration actions (September 2014) and the second assessment was carried out 12 months later (October 2015). The species were identified in the field and with specialists' help from the Herbarium of the Department of Forest Sciences, Federal University of Santa Maria. The identification of botanical families followed Angiosperm Phylogeny Group IV (APG IV, 2016).

Shannon's Diversity $\left(\mathrm{H}^{\prime}\right)$ and Pielou's Evenness $\left(\mathrm{J}^{\prime}\right)$ indexes (MAGURRAN, 2013) were calculated using PAST software, version 1.79, and then the Shannon's Diversity $\left(\mathrm{H}^{\prime}\right)$ results for each spring and each assessment were compared using the Hutcheson t-test (HUTCHESON, 1970). The richness and abundance from each spring and each 
Table 1 - Summary of conservation state, disturbance source, characteristics and ecological restoration method in six spring in Arroio Manoel Alves sub-hydrographic basin, Southern Brazil.

\begin{tabular}{|c|c|c|c|c|}
\hline $\mathrm{N}$ & Conservation state & Disturbance source & Characteristics & $\begin{array}{l}\text { Ecological } \\
\text { restoration method }\end{array}$ \\
\hline N1 & Disturbed & $\begin{array}{l}\text { Suppression of natural vegetation for } \\
\text { planting eucalyptus and cattle free } \\
\text { access }\end{array}$ & $\begin{array}{l}10 \mathrm{~m} \text { radium of natural vegetation } \\
\text { around the spring; Eucalyptus sp. } \\
\text { forestry and pasture }\end{array}$ & Applied nucleation \\
\hline $\mathrm{N} 2$ & Degraded & $\begin{array}{l}\text { Suppression of natural vegetation for } \\
\text { planting eucalyptus and cattle free } \\
\text { access }\end{array}$ & $\begin{array}{c}\text { Eucalyptus sp. forestry and } \\
\text { pasture }\end{array}$ & $\begin{array}{l}\text { Total area seedling } \\
\text { planting }\end{array}$ \\
\hline N3 & Degraded & $\begin{array}{l}\text { Suppression of natural vegetation for } \\
\text { planting eucalyptus and cattle free } \\
\text { access }\end{array}$ & $\begin{array}{c}\text { Eucalyptus sp. forestry and } \\
\text { pasture }\end{array}$ & Passive restoration \\
\hline N4 & Disturbed & Cattle free access & Natural vegetation & Passive restoration \\
\hline N5 & Disturbed & Cattle free access & $\begin{array}{c}\text { Natural vegetation and } \\
\text { Eucalyptus } \mathrm{sp} \text {. forest }\end{array}$ & Passive restoration \\
\hline N6 & Disturbed & Cattle free access & $\begin{array}{l}\text { Isolated site eight years ago in } \\
\text { earlier to medium succession } \\
\text { stage }\end{array}$ & $\begin{array}{l}\text { Passive restoration } \\
\text { for } 8 \text { years }\end{array}$ \\
\hline
\end{tabular}

Where: N: Spring habitat.

Source: Adapted from PIAIA et al. (2015).

assessment were compared using the KruskalWallis test $(\mathrm{P}<0.05)$. Significant differences between springs and assessment were compared by the t-test $(\mathrm{P}<0.05)$ using the $\mathrm{R}$ software package 'agricolae' (MENDIBURU, 2019; R Development Core Team, 2019). The floristic composition similarity of the springs was verified by Detrended Correspondence Analysis (DCA), carried out using the CANOCO 4.5 statistical software. DCA used a species matrix for each assessment containing data on the presence and absence in each plot.

\section{RESULTS AND DISCUSSION}

A total of 1039 individuals from 29 botanical families and 76 species were verified in six springs in the two assessments. Five species were identified only in genera and eight species could not be identified. We verified 420 individuals belonging to 20 families and 46 species in the six springs studied before isolating and implementing the restoration approaches in 2014. Then after 12 months of the restoration actions, 620 individuals, 30 families and 67 species were sampled in 2015. Myrtaceae was the family with the largest number of species (14), followed by Fabaceae (5), Sapindaceae (4) and Euphorbiaceae (4). The Myrtaceae family has a large number of arboreal representatives in all phytogeographic types in Rio Grande do Sul.
This family is known for its high representation in the arboreal communities of the seasonal forest, as well as Fabaceae, Euphorbiaceae and Sapindaceae (FÁVERO et al., 2015, SCIPIONI et al., 2009). Myrtaceae has an important role in the diet of frugivorous birds (CARNEVALE \& MONTAGNINI, 2002). They attract seed dispersing fauna, which is important for ecological restoration.

The species with the highest occurrence were: Blepharocalyx salicifolius (Kunth) O.Berg, Eugenia uniflora L., Calyptranthes concinna DC., Daphnopsis racemose Griseb., Miconia hiemalis A.St.-Hil. \& Naudin ex Naudin, Prunus myrtifolia (L.) Urb., Allophylus guaraniticus (A. St.-Hil.) Radlk., Myrceugenia myrcioides (Cambess.) O. Berg, Gymnanthes klotzschiana Müll.Arg. and Sebastiania brasiliensis Spreng. (Supplementary document). The most abundant species was $B$. salicifolius reported in all springs, except for N3 in both assessments, followed by E. uniflora and $D$. racemosa.

There was a significant increase in richness and abundance in N4 (Table 2), this spring had native forest in medium successional stage, so passive restoration with removing cattle free access allowed the increase. In addition, we verified a significant increase in abundance in N3 (Table 2), which was the spring in more degraded conservation state. In other words, the decision for passive restoration effected by 
Table 2 - Floristic diversity indexes for the six springs under restoration, in 2014 and 2015 assessments, Arroio Manoel Alves subhydrographic basin, southern Brazil.

\begin{tabular}{|c|c|c|c|c|c|c|c|c|c|c|c|c|}
\hline & \multicolumn{6}{|c|}{ 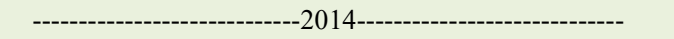 } & \multicolumn{6}{|c|}{------------------------------'2015------------------------------ } \\
\hline & N1 & N2 & $\mathrm{N} 3$ & N4 & N5 & N6 & N1 & N2 & N3 & N4 & N5 & N6 \\
\hline Richness ${ }^{*}$ & $19 \mathrm{~cd}^{*}$ & $18 \mathrm{bc}$ & $3 e$ & $21 \mathrm{bc}$ & $17 \mathrm{bc}$ & $21 \mathrm{bc}$ & $22 b c$ & $21 b c$ & $11 d$ & $29 a$ & $33 \mathrm{bc}$ & $29 \mathrm{ab}$ \\
\hline Families & 11 & 10 & 2 & 12 & 10 & 14 & 14 & 12 & 10 & 16 & 16 & 16 \\
\hline Abundance* $^{*}$ & $71 \mathrm{~cd}^{*}$ & $82 \mathrm{abc}$ & $4 \mathrm{e}$ & $66 \mathrm{~cd}$ & $110 \mathrm{abc}$ & $86 b c$ & $103 b c$ & $10 \mathrm{abc} 3$ & $33 d$ & $162 \mathrm{a}$ & $91 \mathrm{bc}$ & $128 \mathrm{ab}$ \\
\hline $\mathrm{H}^{* * *}$ & $2.41 a b^{* *}$ & $2.47 \mathrm{ab}$ & $\begin{array}{c}1.04 \\
\mathrm{c}\end{array}$ & $2.76 a$ & $2.40 \mathrm{~b}$ & $2.76 \mathrm{a}$ & $2.70 \mathrm{ab}$ & $2.65 \mathrm{ab}$ & $\begin{array}{c}1.73 \\
\mathrm{c}\end{array}$ & $\begin{array}{c}2.85 \\
\mathrm{a}\end{array}$ & $3.07 \mathrm{a}$ & $2.96 \mathrm{a}$ \\
\hline $\mathrm{J}^{\prime}$ & 0.62 & 0.62 & 0.94 & 0.75 & 0.65 & 0.75 & 0.68 & 0.67 & 0.51 & 0.59 & 0.66 & 0.66 \\
\hline
\end{tabular}

Where: N1: spring habitat in applied nucleation; N2: total area seedling planting; N3: degraded spring habitat in passive restoration; N4: disturbed native vegetation in passive restoration; N5: disturbed spring habitat in passive restoration; N6: spring habitat in passive restoration for eight years; H': Shannon index; J': Pielou's Evenness Index. *Richness and Abundance followed by the same letter for springs and assessment do not differ by the Kruskal-Wallis test $(\mathrm{P}<0.05)$. ** Shannon's index followed by the same letter for springs and assessment does not differ from each other by the Hutcheson t-test $(\mathrm{P}<0.05)$.

the fencing and exclusion of the degradation factor (cattle) could contribute to the expression of natural regeneration in the short-term after the restoration actions. Passive restoration can favor biodiversity recuperation in areas of environmental liability, as long as there are adequate resilience levels helping to increase connectivity in fragmented landscapes (ROVEDDER et al., 2018).

The N4 (disturbed native vegetation in passive restoration), N5 (disturbed spring habitat in passive restoration) and N6 (eight years passive restoration) springs showed the highest floristic diversity in both assessments (Table 2). Moreover, the N5 spring showed a significant increase in diversity in 12 months (Table 2). These results can be attributed to local resilience with the greater range of native vegetation surrounding these springs (Table 1), which works as a propagule source and facilitates the circulation of seed dispersers. The longer time under passive restoration (eight years) in N6 may have contributed to greater diversity, while N3 presented the lowest floristic diversity in both assessments, confirming the degradation state of this spring due to pasture and Eucalyptus sp. forest.

The Detrended Correspondence Analysis (DCA) for the 2014 assessment presented $68,42 \%$ of the variance explanation in the first axis (Figure 2). N6 and N5 showed a distinct floristic composition and were not related to any other spring. N1 approached N4, these springs had natural vegetation in medium successional stage and presented in 2014 assessment most pioneer or climax light tolerant species as Myrceugenia myrcioides (Cambess.) O. Berg, Zanthoxylum rhoifolium Lam, Nectandra megapotamica (Spreng.) Mez, Blepharocalyx salicifolius (Kunth) O.Berg, Eugenia uniflora L. Only N3 was not related to a specific species group in 2014 assessment, possibly due to its condition of degradation. Studies have confirmed the harmful effect of the presence of cattle in forest remnants with destruction of the seedling bank and the soil seed bank, reduced floristic diversity, number of individuals and increased potential for biological invasion (JESUS et al., 2018; STEFANELLO et al., 2019). The cattle effect in the short term was a decrease in regenerating individuals, and in the long term an increase in the degree of soil compaction, which may be an impediment to seedling development (EATON et al., 2016).

The DCA for the assessment carried out in 2015 showed a new floristic composition pattern (Figure 3). The eigenvalue for the first axis was $56.93 \%$, summarizing more than half of the data variation. The N6 approached N1 and N4 springs in 2015. N5 showed a distinct floristic composition and did not approached to any other spring in 2015 , as we verify in 2014 assessment. The fact that N5 (disturbed spring habitat in passive restoration) showed a distinct floristic composition in both assessments may be related to a native forest in medium to 


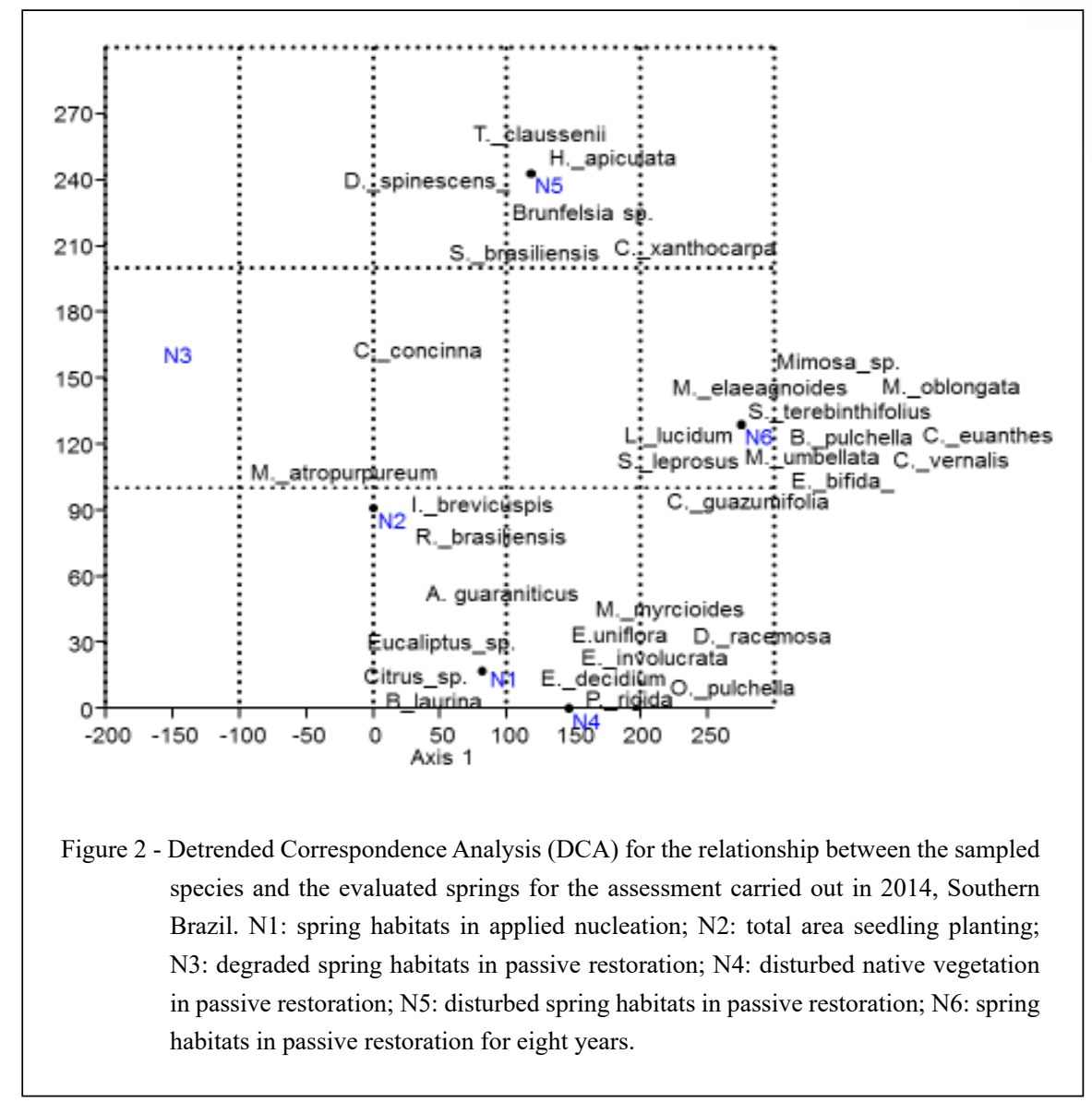

advanced successional stage in half part of PPA zone, which contributed to resilience levels. We can highlight some of climax shade tolerant and climax light tolerant species that occur exclusively in N5 in 2015: Trichilia elegans A. Juss., Campomanesia xanthocarpa O. Berg, Cedrela fissilis Vell., Banara tomentosa Clos, Eugenia hiemalis Cambess., Eugenia uruguayensis Cambess and Helietta apiculata Benth.

The spring under passive restoration for eight years (N6) showed association with numerous species, some of which are exclusive to this spring, which possibly influenced that the first assessment did not show similarity with any other springs. We can highlight Escallonia bifida Link \& Otto, Cupania vernalis Cambess. and Mimosa sp. as exclusive species. C. vernalis is one of the main specie to compose the seed bank and the regenerative stratum under shade in seasonal forests (GIEHL et al., 2007), which demonstrated the effectiveness of the passive restoration effected by the fence for the return of conditions to species establishment in N6. DCA showed the species Schinus terebinthifolia Raddi, Matayba elaeagnoides Radlk., Prunus myrtifolia
(L.) Urb., Styrax leprosus Hook. \& Arn., Cestrum euanthes Schltdl. and Bernardia pulchella (Baill.) Müll. Arg.. more associated with N6 spring in 2015 assessment.

In relation of invasion exotic species, Hovenia dulcis Thunb. and Ligustrum lucidum W. T. Aiton occurred exclusively in N6 (eight years passive restoration) and Citrus sp. occurred exclusively in N2 (total area seedling planting). Although, the density of individuals for these species was low; this fact deserves attention since biological invasion by exotic species is one of the main problems of passive restoration (PRACH et al., 2019). The interpretation of resilience and biological invasion levels must be realized carefully. Studies in the same region have highlighted the issue of biological invasion, with emphasis on the presence of H. dulcis, L. Lucidum (HUMMEL et al. 2014; ROVEDDER et al., 2018).

DCA showed association with Celtis iguanaea (Jacq.) Sarg., Lonchocarpus campestris Mart. ex Benth. and Erythroxylum deciduum A.St.Hil. for N2 spring in 2015 assessment and for 2014 assessment we verify Ilex brevicuspis Reissek 


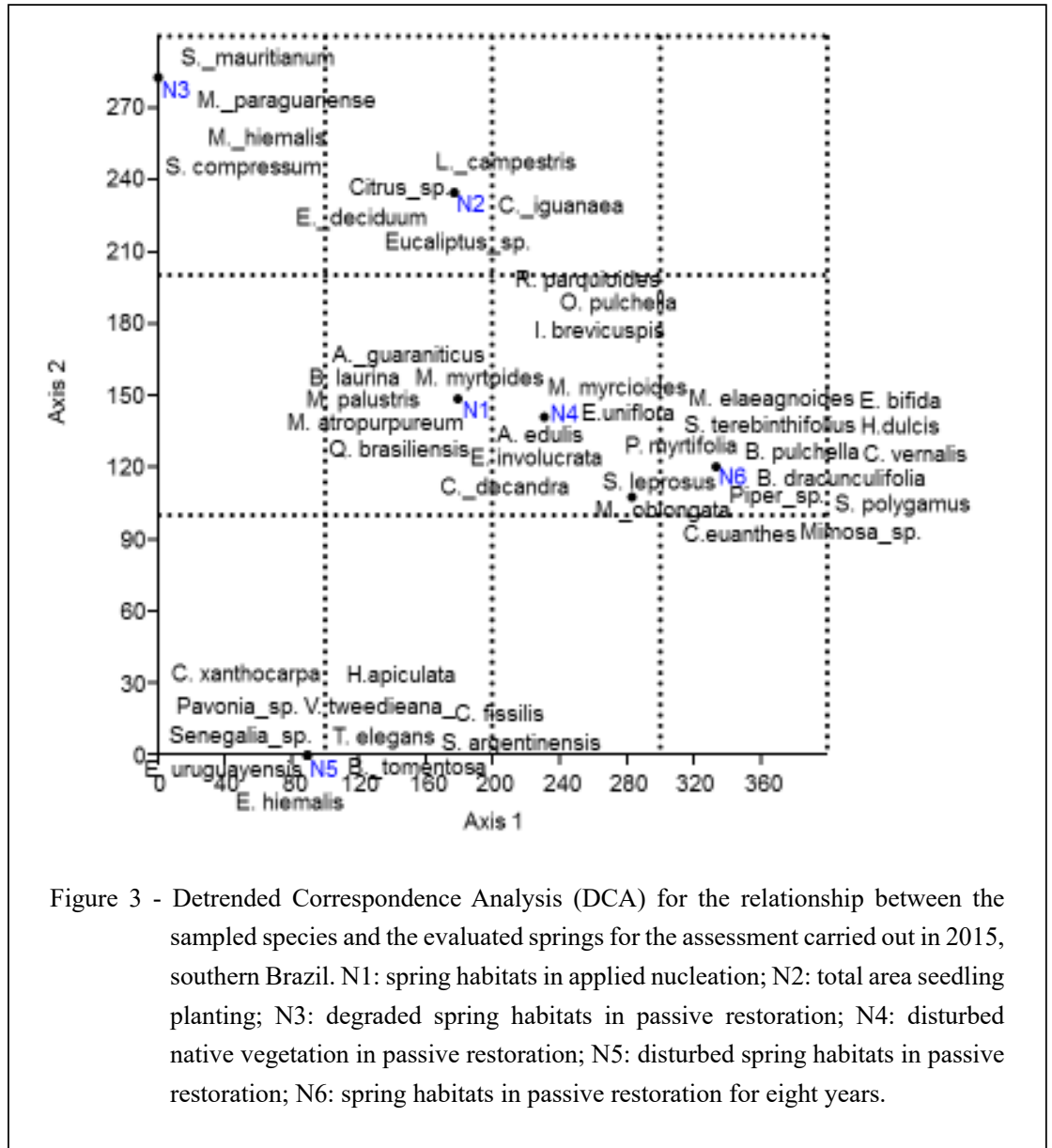

and Rubus brasiliensis Mart. Despite the applied nucleation in N1 and total area seedling planting in N2, the main effect observed in the short term was due to the enclosure and cattle removal in these springs. N3 spring presented association with Solanum mauritianum Scop, Miconia hyemalis A.St.-Hil. \& Naudin ex Naudin, and Machaerium paraguariense Hassl in 2015, while in 2014 we did not verify association with species in this spring. The Miconia and Solanum genera are pioneer shrubs with a short life cycle and they colonize large clearings (TABARELLI \& MANTOVANI, 1999), confirming the initial successional stage of this spring.

The composition of forest species in early communities is a reflection of local colonization patterns and the effects of remaining vegetation (CHAZDON et al., 2007). The positive results in increasing diversity and density, even in a short term of 12 months, reflect the presence of the remaining vegetation around some springs and corroborate the
Ministry of the Environment's classification for the potential of natural regeneration of the Atlantic Forest in same region (SANSEVERO et al., 2018).

\section{CONCLUSION}

The floristic composition of springs habits was singular and distinct from each disturbed and degraded source. The local resilience and the remaining vegetation in different states of successional stage in the springs influenced the natural regeneration floristic composition patterns. Passive restoration carried out by fencing and cattle removing favored natural regeneration tree recruitment in the short term.

\section{ACKNOWLEDGEMENTS}

We thank Petrobras for the sponsorship, through the Programa Petrobras Socioambiental; the landowner for granting 
us access to their areas; and Coordenação de Aperfeiçoamento de Pessoal de Nível Superior (CAPES) for the doctorate scholarship granted to the first author through the Graduate Program in Forest Engineering at the Federal University of Santa Maria (UFSM). Finally, we would like to thank the two reviewers and the editor whose feedback helped to improve our manuscript.

\section{DECLARTION OF CONFLICT OF INTERESTS}

The authors declare no conflict of interest. The founding sponsors had no role in the design of the study; in the collection, analyses, or interpretation of data; in the writing of the manuscript, and in the decision to publish the results.

\section{AUTHORS' CONTRIBUTION}

All authors contributed equally to the manuscript.

\section{REFERENCES}

ALVARES, C.A. et al. Köppen's climate classification map for Brazil. Meteorologische Zeitschrift, Stuttgart, v.22, n.6, p.711728, 2013. Available from: <http://dx.doi.org/10.1127/09412948/2013/0507>. Accessed: Mar. 18, 2019.

APG IV. An update of the Angiosperm Phylogeny Group classification for the orders and families of flowering plants: APG IV. Botanical Journal of the Linnean Society, v.181, p.120, 2016. Available from: <https://doi.org/10.1111/boj.12385>. Accessed: Apr. 03, 2019.

BECHARA, F. C. et al. Neotropical rainforest restoration: comparing passive, plantation and nucleation approaches. Biodiversity and Conservation, v. 25, n. 11, p. 2021-2034, 2016. Available from: <https://doi.org/10.1007/s10531-016-1186-7>.

BRASIL. Lei n. 12.651, de 25 de maio de 2012, Revoga a Lei $\mathrm{n}^{\text {o }} 4.771$ de 15 de setembro de 1965, que dispõe sobre a proteção da vegetação nativa.Diário Oficial [da] República Federativa do Brasil. Brasília, DF, 25 mai, 2012. Disponível em: <http:// www,planalto,gov,br/ccivil_03/_ato2011-2014/2012/lei/ 112651,htm>. Access: 16 Aug, 2020.

BOESING, A.L. et al. Biodiversity extinction thresholds are modulated by matrix type. Ecography, v.41, p.1-14, 2018. Available from: <https://doi.org/10.1111/ecog.03365>. Accessed: Apr. 03, 2019.

CARNEVALE, N.J.; MONTAGNINI, F. Facilitating regeneration of secundary forests with the use of mixed and pure plantations of indigenous tree species. Forest Ecology and Management, Netherlands, v.163, p.217-227, 2002. Available from: $<$ https://doi. org/10.1016/S0378-1127(01)00581-3>. Accessed: Apr. 03, 2019.

CHAZDON, R.L. et al. Rates of change in tree communities of secondary Neotropical forests following major disturbances. Philosofical Transactions of the Royal Society B: Biological Sciences, v.362, n.2, p.273-289, 2007. Available from: <https:// doi.org/10.1098/rstb.2006.1990>. Accessed: Apr. 03, 2019.

CROUZEILLES, R. et al. Ecological restoration success is higher for natural regeneration than for active restoration in tropical forests. Science Advances, v. 3, p. 1-7, 2017. Available from: <https://doi. org/10.1126/sciadv.1701345>. Accessed: Apr. 03, 2019.
EATON, D.P. et al. Citizen scientists help unravel the nature of cattle impacts on native mammals and birds visiting fruiting trees in Brazil's southern Pantanal. Biological Conservation, p.1-11, 2016. Available from: <https://doi.org/10.1016/j.biocon.2016.09.010>. Accessed: Apr. 03, 2019.

FÁVERO, A.A. et al. Species abundance distribution in tree community of a hill top in subtropical seasonal forest. Ciência Rural, v.45, n.5 p.806-813, 2015. Available from: <http://dx.doi. org/10.1590/0103-8478cr20121238>. Accessed: Apr. 03, 2019.

FLOSS, P.A. et al. Environmental structure and relationships in the setting of natural water springs in a Lower Highland Seasonal Forest in Brazilian South. Ciencia Rural, v.48, n.11, 2018. Available from: $\quad<$ http://dx.doi.org/10.1590/0103-8478cr20170857>. Accessed: Apr. 03, 2019.

HUMMEL, R.B. et al. Preliminary analysis of biological invasion by Ligustrum lucidum W.T. Aiton in protected areas in Rio Grande Do Sul. Caderno de Pesquisa, série Biologia, v.26, n.3, p.14-26, 2014.

HUTCHESON, K. A test for comparing diversities based on the Shannon formula. Journal of Theoretical Biology. v.29, p.151154, 1970. Available from: <http://dx.doi.org/10.1016/00225193(70)90124-4>. Accessed: Apr. 03, 2019.

IBGE - INSTITUTO BRASILEIRO DE GEOGRAFIA E ESTATÍSTICA. Manual técnico da vegetação brasileira. Rio de Janeiro, RJ - Brasil, 2012. Disponível em: <ftp://geoftp.ibge. gov.br/documentos/recursos_naturais/manuais_tecnicos/manual_ tecnico_veg etacao_brasileira.pdf $>$. Acesso em: 20, nov. 2018.

JESUS, J.B. et al. Floristic composition and characterization of the conservation state of springs from the central east portion of the Itapicuru river watershed in the Bahiasemiarid. Floresta, v.48, n.2, p.245-254, 2018. Available from: <https://doi.org/10.5380/ rf.v48i2.55540>. Accessed: Apr. 03, 2019.

MAGURRAN, A. E. Medindo a diversidade biológica. Tradução Dana Moina Vianna. Editora UFPR. 2013. 261p.

MARCHIORI, J.N.C. Fitogeografia do Rio Grande do Sul: enfoque histórico e sistemas de classificação. Porto Alegre: EST, 2002, 118 p.

MARTIN, D.M. Ecological restoration should be redefined for the twenty-first century. Restoration Ecology, v.25, n.5, p.668673, 2017. Available from: <https://doi.org/10.1111/rec.12554>. Accessed: Apr. 03, 2019.

MEA - Millenium Ecosystem Assessment. Ecosystems and human well-being: current state and trends - findings of the Condition and Trends Working Group. Island Press, Washington DC. 2005.

MENDIBURU, F de Package 'agricolae'. R package version 1.3-0. Available from: <https://cran.r-project.org/web/packages/ agricolae/agricolae.pdf. 2019>. Accessed: Apr. 03, 2019.

MMA - Ministério do Meio Ambiente, Brasil 2017. Potencial de Regeneração Natural da vegetação no Brasil. Ministério do Meio Ambiente - MMA, World Resources Institute - WRI Brasil. Brasília, DF: MMA, 2017.

NERY, E.R.A. et al. O conceito de restauração na literatura científica e na legislação brasileira. Revista Caititu, Salvador, v.1, 
n.1, p.43-56, 2013. Available from: <http://dx.doi.org/10.7724/ caititu.v1i1.5202>. Accessed: Apr. 03, 2019.

PIAIA, B.B. et al. Floristic of Permanent Preservation Area in springs with different levels of conservation at sub-basin Arroio Manoel Alves in Itaara, RS. Enciclopédia Biosfera. Centro Científico Conhecer, Goiânia, v.11, n.22, p.1306, 2015. Available from: <http://dx.doi.org/10.18677/Enciclopedia Biosfera_2015_161>. Accessed: Apr. 03, 2019.

PRACH, K. et al. Possibilities and limitations of passive restoration of heavily disturbed sites. Landscape Research, p.1-7. 2019. Available from: <https://doi.org/10.1080/01426397.2019.159333 5>. Accessed: Apr. 03, 2019.

R Development Core Team R: A language and environment for statistical computing. R Foundation for Statistical Computing, Vienna, Austria. 2018. ISBN 3-900051-07-0, Available from: $<$ http://www.R-project.org > . Accessed: Apr. 03, 2019.

RODRIGUES R. R. et al. On the restoration of high diversity forests: 30-year experience in the Brazilian Atlantic Forest. Biological Conservation, v. 142, p. 1242-1251, 2009. Available from: < https://doi.org/10.1016/j.biocon.2008.12.008>. Accessed: Apr. 03, 2019.

RODRIGUES, R. R. et al. Large-scale ecological restoration of high-diversity tropical forests in SE Brazil. Forest Ecology and Management, v. 261, n. 10, p. 1605-1613, 2011. Available from: $<$ https://doi.org/10.1016/j.foreco.2010.07.005>. Accessed: Apr. $03,2019$.

ROVEDDER, A. P. M. et al. Perspectivas da restauração ecológica de ecossistemas para o Rio Grande do Sul. In: DÖRR,
A. C.; ROSSATO, M. V.; ROVEDDER, A. P. M.; PIAIA, B. B. (Org.) Práticas e saberes em meio ambiente. Curitiba, Appris, 2014. 360p.

ROVEDDER, A.P.M. et al. Natural regeneration in Conservation Unit: subsidy for restoration actions. Floresta e Ambiente, v.24, n.4, e20170821, 2018. Available from: $<$ http://dx.doi.org/10.1590/2179-8087.082117. Accessed: Apr. 03, 2019.

ROVEDDER, A.P.M. et al. Potential medicinal use of forest species of the Deciduous Seasonal Forest from Atlantic Forest Biome, South Brazil. Brazilian Archives of Biology and Technology, v.59, p.1-11, 2016.

SANSEVERO, J.B.B. et al. Potencial de regeneração natural no Bioma Mata Atlântica. Ministério do Meio Ambiente, 9 p., 2018. SCIPIONI, M.C. et al. Natural regeneration of a Decidual Forest fragment in the Biological Reserve of the Ibicuí-Mirim (RS). Floresta, v.39, n.3, p.675-690, 2009. Available from: $<$ https://doi. org/10.5380/rf.v39i3.15369>. Accessed: Apr. 03, 2019.

STEFANELLO, M.M. et al. How Bovine Livestock Affects Seed Rain in Subtropical Climate Forest. Journal of Agricultural Science, v.11, n.10, 10p., 2019.

STRECK, E.V. et al. Solos do Rio Grande do Sul. Porto Alegre: EMATER/RS; 2 ed, UFRGS, 2008, 222 p.

TABARELLI, M.; MANTOVANI, W. Pioneer species richness in a tropical montane forest. Revista Brasileira de Biologia, São Paulo, v.59, n.2, p.251-261, 1999. Available from: <http:// dx.doi.org/10.1590/S0034-71081999000200009>. Accessed: Apr. 03, 2019. 